\title{
Student's Privacy and Self Presentation in Social Networking Site
}

\author{
Fridayanti, Fenti Hikmawati, Anjani Pratiwi \\ Faculty of Psychology \\ UIN Sunan Gunung Djati \\ Bandung, Indonesia \\ fridayanti@uinsgd.ac.id
}

\begin{abstract}
Self-presentation in social media has become a phenomenon in the digital era today, especially in the student as adolescents. This study aims to examine the influence of teen privacy on self-presentation in social media. Total Subjects in this study as many as 189 students of high school students, with details of 139 female students and 50 male students. The average age of the subject is $\mathbf{1 6 . 6}$ years. Data collection using survey method with the instrument in the form of two questionnaires namely The Social Preference Questionnaire (SPQ) and The Efficacious Self-Presentation Scale (ESS). Data were analyzed using simple linear regression analysis technique. The results of this study show that there is a significant effect of privacy toward self-presentation in social media, with a negative direction of influence. The resulting fitted linear regression line was given by $Y$ (Self-presentation) $=125.515$ Privacy -0.442 . This result indicates that the more student has the privacy, the less there will be present them self on Instagram.
\end{abstract}

Keywords-social networking site; instagram; selfpresentation; privacy

\section{INTRODUCTION}

High school student in this last few years has been exposed to all types of technologies in many aspects of their lives[1], including social networking sites (SNSs). Their Participation in SNS has dramatically increased in recent years. As an adolescent, they are searching for the identity. SNSs, such as Instagram and Facebook can facilitate their searching, by comparing their looks and image among them (Mascheroni, Vincent, \& Jimenez, 2015). Nowadays, It is usual for students to post their self-portrait photographs or "selfies" of themselves and sharing their photos to observe and compare themselves against their peers [2] As a visual platform for photo sharing, Instagram has become one of the most popular and influential social networks. The site has more than 400 million actives. Many adolescences also participate in Instagram and spend most of the time on it. They became more engaged in online self-presentation. Besides the positive impact of SNS, there is growing concern of about internet safety in social media. As they more engage to engage with, they also share their personal information on SNS. Adolescent tend to disclose personal information on their profiles. Analyses of profiles have found that SNS users provide a large amount of personal information on public profiles. Gross and Acquisti (2005) analyzed profiles of more than 4000 students and found that only a small percentage of users had changed the default privacy settings on SNSs [3]. SNS become a medium for self-presentation, nearly $50 \%$ of individual uploads are grouped as examples of selfpresentation in social media [4].Based on the information they provide online, adolescence exposes themselves to various physical and cyber risks. They share their profile make it easy for third parties to create digital dossiers of their behavior. Because potential risk to their security, therefore, it is important to study the adolescence's present their self in SNSs.

Self-presentation consists of behaviors which are intended to manage the impressions that observers have of actors [5]. claim for themselves. To achieve this goal, individuals must present themselves in accordance with their social roles, and make sure others positively evaluate their images. The goal of this behavior is to make others accept the images individuals claim for themselves. Many studies identify the social factor, such as peer group as main cause for people to present their self. The reason is that of their need to belong and be accepted by the peer groups, friends are significant reference points and comparison targets for adolescents (Krayer, Ingledew, \& Iphofen, 2008.

Arkin (1981) suggests, self-presentation behaviors are not only affected by external but also by the internal factor [6]. Unfortunately, there is still small amount study which focuses on internal factors that influence self-presentation in social media. Due to the security and risk of social media, privacy is the critical issues in social media. Therefore, we focus this study on privacy as one internal characteristic of participant od SNSs. Privacy is as crucial as openness to others. Privacy is essential to person's individual and relational wellbeing. Privacy may become the driving motivations for much interpersonal behavior [7]. Privacy is the ability to control and limit physical, interactional, psychological and informational access to self or one's group [8]. One study analyzed privacy and security risks for SNSs users and demonstrated how to manage those risks [8]. Other studies show that Study about how one's participating use SNSs (Facebook), Depend on the participants' privacy management practices [8]. The purpose of this research is to examine how privacy influence selfpresentation. 


\section{THEORETICAL BACKGROUND}

\section{A. Efficacious Self Presentation}

An efficacious self-presentation is the ability to regulate selfimage and social openness [9]. Highly efficacious selfpresentation subjects regulate their behavior to the social climate around them, monitoring and controlling the image they present in order to deal with different social conditions, and change their attitude in line with whomever they have in front of them. The ability to attune an individual's own social image could be either the result of a manipulative attitude to selectively present aspects of personality, omitting revealing information to maximize a positive impression, or could be the expression of a greater openness to social experience. On the other hand, poorly efficacious self-presentation subjects display more consistent behavior across various social contexts, independently of contextual covert and overt demands. They tend to act in a similar manner because they are not influenced by social rules [9]

\section{B. Privacy}

Privacy is conceived of as an interpersonal boundary process by which a person or group regulates interaction with others. By altering the degree of openness of the self to others, a hypothetical personal boundary is more or less receptive to social interaction with others. Privacy is, therefore, a dynamic process involving selective control over a self-boundary, either by an individual or by a group (p.6) [1]. Privacy represents control over the amount of interaction one's choose to maintain with others [10]. If one can choose how much or how little to divulge about oneself to another voluntarily, privacy is maintained. If another person can influence how much information we divulge about ourselves or how much information input we let in about others, a lower level of privacy exists

\section{RESEARCH METHOD}

\section{A. Participant}

Given the specific interest in adolescent, the data were collected from the student from 139 students from one high school in Bandung, West Java Indonesia. They're aged between 15-18. Total of participants was 189 (50 males, 139 females). The requirement for participating in this study was having an Instagram account. For this purpose, the first page contained only one question: "Do you have an Instagram account?" Only those who replied "Yes" were directed to the questionnaire; meanwhile, those who replied "No" were thanked for their time

\section{B. Material and procedures}

After responding to demographic questions, the participants answer two questionnaires. The first is The Social Preference Questionnaire (SPQ) develop by Pedersen (1979) and revised by Rustemli \& Kokdemir (1992). This scale using 5 points Likert scale. The scale consists 30 items. Reliability was tested using Cronbach alpha $(\alpha=0.591)$ The second questionnaire is The Efficacious Self-Presentation Scale (ESS) develop by Laghi, Pallini, Alessio dan Baioco (2011). This scale is using 6 points Likert scale, consist of 22 items. Reliability was found acceptable $(\alpha=0,550)$.

\section{Data analysis and result}

We conduct bivariate analyses relating to independent variables to test the hypothesis using The Statistical Package for the Social Sciences (SPSS version 18.0)

\section{RESULT AND DISCUSSION}

\section{A. Test of assumption}

The data collected from respondents were analysis first to test the assumption using test of normality, linearity and multicollinearity. From result of normality test (Table I), asymp value is $0.715(0.715>0.05)$. From this result, we conclude that the data is distributed normally. From result of linearity test (table II), significance value $0.390 \quad(0.390>005$ With $\mathrm{F}=1.807$ and 188 degrees of freedom). This result shows that the test is statistically significant, we conclude that there is a linear regression between the variables between privacy and self-presentation. From the test result of heteroskedasticity test (table III), the significance value is $0.355(0.355>0.05)$. This result means that there is no heteroskedasticity. These From these result, the data confirmed the assumptions of normality, linearity, and heteroskedasticity. It means that we can use this data for analysis of the significance.

\section{1) Normality Test}

TABLE I. NoRmality Test Result

One-Sample Kolmogorov-Smirnov Test

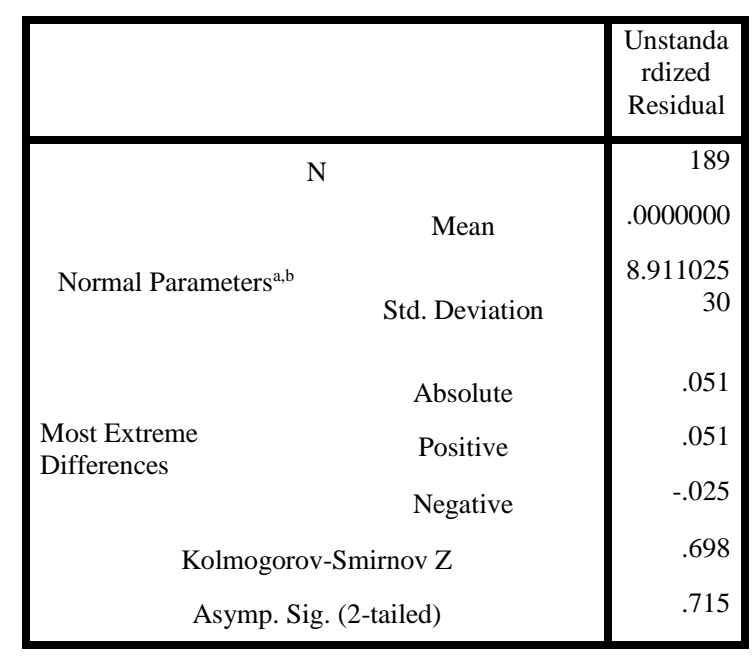

${ }^{\text {a. }}$ Test distribution is Normal.

${ }^{\text {b. }}$ Calculated from data. 


\section{2) Linearity test}

TABLE II. LINEARITY TEST RESULT

\begin{tabular}{|c|c|c|c|c|c|c|c|}
\hline \multicolumn{8}{|c|}{ ANOVA Table } \\
\hline & & & $\begin{array}{c}\text { Sum of } \\
\text { Squares }\end{array}$ & df & $\begin{array}{c}\text { Mean } \\
\text { Square }\end{array}$ & $\mathrm{F}$ & Sig. \\
\hline \multirow{5}{*}{$\begin{array}{c}\text { Presentasi } \\
\text { Diri * } \\
\text { Privasi }\end{array}$} & \multirow{3}{*}{$\begin{array}{c}\text { Between } \\
\text { Groups }\end{array}$} & (Combined) & 4993.743 & 35 & 142.678 & 1.807 & .008 \\
\hline & & Linearity & 2144.840 & 1 & 2144.840 & 27.167 & .000 \\
\hline & & $\begin{array}{l}\text { Deviation } \\
\text { from } \\
\text { Linearity }\end{array}$ & 2848.903 & 34 & 83.791 & 1.061 & .390 \\
\hline & \multicolumn{2}{|c|}{ Within Groups } & 12079.495 & 153 & 78.951 & & \\
\hline & \multicolumn{2}{|l|}{ Total } & 17073.238 & 188 & & & \\
\hline
\end{tabular}

\section{3) Heteroskedasticity test}

TABLE III. HETERoskedAsticity TeSt RESUlt

Coefficients

\begin{tabular}{|cc|ccc|cr|}
\hline \multicolumn{1}{|c|}{ Model } & \multicolumn{2}{|c|}{$\begin{array}{c}\text { Unstandardized } \\
\text { Coefficients }\end{array}$} & $\begin{array}{c}\text { Standardized } \\
\text { Coefficients }\end{array}$ & $\mathrm{t}$ & \multirow{2}{*}{ Sig. } \\
\hline & & $\mathrm{B}$ & Std. Error & Beta & & \\
\cline { 3 - 7 } 1 & $\begin{array}{c}\text { (Constant) } \\
\text { PRIV }\end{array}$ & 3.958 & 3.238 & & 1.223 & .223 \\
\cline { 3 - 7 } & & .049 & .053 & .068 & .927 & .355 \\
\hline
\end{tabular}

a. Dependent Variable: Residual

\section{B. Hypothesis testing}

TABLE IV. COEFFICIENT OF DETERMINATION TEST RESUlt Model Summary

\begin{tabular}{|c|r|r|r|r|}
\hline Model & R & R Square & $\begin{array}{c}\text { Adjust } \\
\text { ed R } \\
\text { Square }\end{array}$ & $\begin{array}{l}\text { Std. Error of } \\
\text { the Estimate }\end{array}$ \\
\hline 1 & $.354^{\mathrm{a}}$ & .126 & .121 & 8.935 \\
\hline
\end{tabular}

b. Dependent Variable: PD

TABLE V. COEFICIENT OF DETERMINATION TEST RESUlT

\begin{tabular}{|c|c|c|c|c|c|c|}
\hline \multicolumn{7}{|c|}{ ANOVA } \\
\hline \multirow{4}{*}{1} & Model & $\begin{array}{c}\text { Sum of } \\
\text { Squares }\end{array}$ & df & $\begin{array}{c}\text { Mean } \\
\text { Square }\end{array}$ & $\mathrm{F}$ & Sig. \\
\hline & \multirow{3}{*}{$\begin{array}{c}\text { Regression } \\
\text { Residual } \\
\text { Total } \\
\end{array}$} & 2144.840 & 1 & 2144.840 & \multirow[t]{3}{*}{26.867} & \multirow[t]{3}{*}{$.000^{\mathrm{b}}$} \\
\hline & & 14928.398 & 187 & 79.831 & & \\
\hline & & 17073.238 & 188 & & & \\
\hline
\end{tabular}

a. Dependent Variable: PD

b. Predictors: (Constant), PRIV

TABLE VI. REGRESSION COEFFICIENT TEST RESULT

Coefficients

\begin{tabular}{|c|c|c|c|c|c|}
\hline \multirow[t]{2}{*}{ Model } & \multicolumn{2}{|c|}{$\begin{array}{l}\text { Unstandardized } \\
\text { Coefficients }\end{array}$} & \multirow{2}{*}{$\begin{array}{c}\begin{array}{c}\text { Standardized } \\
\text { Coefficients }\end{array} \\
\text { Beta }\end{array}$} & \multirow[t]{2}{*}{$\mathrm{t}$} & \multirow[t]{2}{*}{ Sig. } \\
\hline & B & $\begin{array}{l}\text { Std. } \\
\text { Error }\end{array}$ & & & \\
\hline (Constant) & 125.515 & 5.190 & & 24.185 & .000 \\
\hline PRIV & -.442 & .085 & -.354 & -5.183 & .000 \\
\hline
\end{tabular}

a. Dependent Variable: PD
From the table above, we conclude that there is a significant regression equation was found $(\mathrm{F}(1,187)=26.867$, $p<.000)$, with an $R^{2}$ of .126 Linear regression analysis estimates the linear regression function to be $\mathrm{Y}=125.515$ 0.442) $X$. This data indicates that self-presentation decreases 442 for each measurement scale of privacy

\section{CONCLUSION}

This research provide evidence that self-presentation of an adolescence is a function of their privacy. It means that Privacy can guide how individuals present themselves in social networking site like Instagram. The research result support another study that the need for privacy was a negative predictor of Facebook usage. [11].

\section{REFERENCES}

[1] I. Altman, The environment, and social behavior: privacy, personal space, territory, crowding. Brooks/Cole Pub. Co, 1975.

[2] A. M. Kaplan and M. Haenlein, "Users of the world, unite! The challenges and opportunities of Social Media," Bus. Horiz., vol. 53, no. 1, pp. 59-68, 2010.

[3] R. Gross, A. Acquisti, and H. J. H. Iii, "Information Revelation and Privacy in Online Social Networks," 2005.

[4] L. Bareket-Bojmel, S. Moran, and G. Shahar, "Strategic selfpresentation on Facebook: Personal motives and audience response to online behavior," Comput. Human Behav., vol. 55, pp. 788-795, Feb. 2016.

[5] E. Goffman, The Presentation of Self in Everyday Life, Monograph. The University of Edinburg. Social Science Reseach Centre, 1956.

[6] J. Rui and M. A. Stefanone, "Strategic self-presentation online: A crosscultural study," Comput. Human Behav., vol. 29, no. 1, pp. 110-118, 2013.

[7] J. K. Burgoon, R. Parrott, B. A. Le Poire, D. L. Kelley, J. B. Walther and D. Perry, "Maintaining and Restoring Through communication in Different Types of Relationship," J. Soc. Pers. Relatsh., vol. 6, pp. 131158, 1989.

[8] J. K. Burgoon, "Privacy and Communication," Ann. Int. Commun. Assoc., vol. 6, no. 1, pp. 206-249, Jan. 1982.

[9] F. Laghi, S. Pallini, M. D'Alessio, and R. Baiocco, "Development and Validation of the Efficacious Self- Presentation Scale," J. Genet. Psychol. Res. Theory Hum. Dev., vol. 172, no. 2, pp. 209-219, 2011.

[10] V. J. Derlega and A. L. Chaikin, "Privacy and Self- Disclosure in Social Relationships," J. Soc. Issues, vol. 33, no. 3, pp. 102-115, 1977.

[11] A. Błachnio, A. Przepiorka, W. Boruch, and E. Bałakier, "Selfpresentation styles, privacy, and loneliness as predictors of Facebook use in young people,” Pers. Individ. Dif., vol. 94, pp. 26-31, 2016. 